\title{
SISTEM INFORMASI GEOGRAFI DAN RANTAI PASOK: BAGAIMANA GEOGRAFI DAPAT MEMPERKUAT ANALISIS RANTAI PASOK?
}

\author{
Magdalena Wullur ${ }^{1}$, Joyce Ch. Kumaat ${ }^{2}$ \\ ${ }^{1}$ Program Studi Manajeman, Fakultas Ekonomi dan Bisnis, Universitas Sam Ratulangi \\ ${ }_{2}^{2}$ Program Studi Geografi, Fakultas Ilmu Sosial, Universitas Negeri Manado \\ e-mail: wullurmagdalena@yahoo.com
}

\begin{abstract}
: the paper focuses on transportation (logistics) which is a supply chain management decision-making technique, in the routing decision-making specification. Geographic Information Systems (GIS) take an important role in decision support systems. This system consists of four main parts, namely: decision model, interface, analysis module, and database management system.
\end{abstract}

Keywords: Logistics, System, GIS

\begin{abstract}
Abstrak: Makalah ini fokusnya kepada transportasi (logistics) yang adalah suatu teknik pengambilan keputusan manajemen rantai pasokan, dalam spesifikasi pengambilan keputusan routing. Sistem Informasi Geografis (SIG) mengambil peran penting di dalam sistem pendukung keputusan. Sistem ini terdiri dari empat bagian utama yaitu: model keputusan, antarmuka, modul analisa dan sistem manajemen basisdata.
\end{abstract}

Kata Kunci: Logistik, Sistem, SIG

\section{PENDAHULUAN}

Sistem informasi geografis (SIG) dapat digunakan dalam rantai pasok dengan berbagai cara, tetapi yang utama adalah visualisasi yang lebih baik (Zhang et al., 2016). Pemetaan SIG memberikan informasi secara spasial dan real time dalam mengontrol pergerakan barang, tidak hanya dalam format spreadsheet, pengguna dapat memiliki gambaran visual dan intuitif tentang apa yang terjadi dalam rantai pasok di ujung jari mereka (Irizarry, Karan, \& Jalaei, 2013). SIG menggunakan teknologi GPS bisa memberikan informasi ke tujuan lokasi, tetapi penambahan data SIG adalah merupakan cara yang memungkinkan pengguna untuk membuat keputusan strategis dan taktis secara cerdas. ESRI (Environmental Systems Research Institute) adalah perusahan pembuat perangkat lunak yang menyatukan data, menganalisis dan memetakannya. Jenis informasi ini dapat dilihat sebelumnya dengan alat pemetaan dan data yang di overlay, sehingga user bisa tmengetahui fasilitas manufaktur yang sesuai dan rute transportasi mana yang akan terkena dampak (ESRI, 2019).
Munculnya pasar global telah membawa perubahan besar dalam cara melakukan bisnis: pertama dari produsen sudut pandang statis (paradigma lama), beralih kepada produsen berkonsentrasi pada kompetensi dengan menggunakan aplikasi atau system secara spasial dengan penunjuk lokasi dan outsourcing komponen dan layanan dari pihak ketiga. Kedua dari sudut pandang pelanggan, produk yang lebih baik tersedia dengan harga yang lebih rendah. Ini berarti perusahaan besar dan kecil perlu untuk merampingkan rantai pasokan mereka untuk mendapatkan keunggulan kompetitif. Fokusnya adalah pergeseran dari kinerja perusahaan tunggal untuk bersaing sehingga menjadikan sebuah tantangan dari seluruh rantai pasokan menjadi lebih sederhana (Zhang et al., 2016).

Strategi logistic (Mambu \& Wullur, 2017), dalam pengambilan keputusan transportasi tertentu, dapat dianggap sebagai faktor kunci untuk meningkatkan efektivitas rantai pasokan. Jasa transportasi memainkan suatu peranan penting dalam operasi rantai pasokan yang lancar, pergerakan bahan makanan untuk fasilitas manufaktur, reposisi 
persediaan bahan mentah dari pusat distribusi sehingga memberikan produk jadi kepada pelanggan (Lourenço \& Ravetti, 2018).

Inovasi di dalam pengembangan system khususnya perangkat lunak terbaru dengan mengintegrasikan sistem untuk meningkatkan profitabilitas rantai pasokan secara keseluruhan, perusahaan beralih ke sistem informasi geografis (SIG) sebagai komponen kunci dalam perangkat lunak rantai pasokan mereka. Perangkat lunak pemetaan menyediakan cara mudah bagi pengguna untuk visualisasi data. Ada empat bidang keputusan utama dalam manajemen rantai suplai yaitu $(\mathrm{Wu}$, Cegielski, Hazen, \& Hall, 2013): 1. lokasi, 2. produksi, 3. inventarisasi dan 4. transportasi. Makalah ini fokusnya adalah pada transportasi (logistics) yang adalah suatu teknik pengambilan keputusan manajemen rantai pasokan, dalam spesifikasi pengambilan keputusan routing. Rute yang akan diambil adalah keputusan manajerial yang sangat penting karena keputusan routing mengarah pada keputusan lebih lanjut mengenai penggunaan biaya logistik, waktu perjalanan, dan jarak tempuh (Wu et al., 2013). Oleh karena itu, sebuah Spatial Decision Support System (SDSS) dikembangkan untuk menganalisis rute dan pembuatan rute (rute terbaik dan alternatif untuk rute terbaik).

\section{SISTEM INFORMASI GEOGRAFIS SEBAGAI SISTEM PENDUKUNG KEPUTUSAN SPASIAL}

Untuk Sistem Informasi Geografis dalam mendukung pembuatan keputusan (Zhang et al., 2016), SIG harus dipandang sebagai suatu sistem pendukung keputusan spasial (SDSS). SDSS didefinisikan sebagai: "suatu sistem berbasis komputer interaktif yang membantu dalam pendukung keputusan untuk data dan model". Empat modul kunci dari DSS adalah (Olson \& Kesharwani, 2011):

- Model keputusan

- Antarmuka

- Modul analisis

- Sistem manajemen basis data

Dalam SDSS, modul akan dirancang secara khusus untuk menangani data secara spasial. DBMS akan mengintegrasikan jenis data locational, topologis dan tematik untuk mendukung tampilan kartografi (peta), query spasial dan pemodelan analitis sebagai berbagai skala spasial untuk sejumlah besar variabel. Modul analisis ini akan memiliki struktur analisis spasial yang menyediakan pengguna dengan analisis spasial yang fleksibel dan komprehensif serta kemampuan pemodelan (Zhang et al., 2016). Stukrtur model yang akan mendukung konstruksi dan tampilan dari berbagai model pilihan spasial. Sebuah SIG kemudian memiliki semua fitur dari decision support system (DSS) dan kemampuan untuk mengakomodasi data secara spasial, sehingga dapat digunakan sebagai generator SDSS (Wu et al., 2013).

\section{SISTEM INFORMASI GEOGRAFIS DAN MANAJEMEN RANTAI PASOK}

Sistem informasi geografis (SIG) menawarkan alat manajemen risiko rantai pasokan yang berharga. Analisis SIG memberikan informasi ini secara visual yang sangat berharga, sehingga analisis SIG memungkinkan dapat mengambil keputusan dengan cara memvisualisasikan profil perusahaan yang lengkap yang terdiri dari: lokasi produsen, kantor, gudang, karyawan, klien, pelanggan, distributor dan lokasi pemasok.

SIG membantu bisnis untuk menjawab pertanyaan manajemen rantai pasok seperti:

1. Apa waktu berkendara saya dari fasilitas pusat?

2. Berapa lama waktu yang dibutuhkan untuk mencapai lokasi pengiriman?

3. Pelanggan mana yang harus berada di area Layanan terpisah?

4. Bagaimana saya dapat melacak barang melalui rantai pasokan saya?

SIG lainnya membantu bisnis menjawab pertanyaan transportasi seperti:

1. Apa rute terbaik untuk truk pengiriman?

2. Apa rute alternatif dalam kasus masalah pada satu rute?

Route Analysis adalah suatu analisis yang bertujuan untuk meminimalkan biaya perjalanan yang terlibat dalam pengangkutan barang dari satu lokasi ke tempat lain, baik dalam hal 
perjalanan yang diperlukan atau waktu atau jarak atau kombinasi dari ini (Papinski \& Scott, 2011). Penyajian data rantai pasokan dalam bentuk lokasi di dunia nyata dapat diaplikasikan dengan metode geografi bias diaplikasikan didalam transportasi. Misalnya, satu pengecer mengetahui sistem simpul rantai suplai dengan baik, tetapi ketika rute antara pabrik dan distribusi gudang sebenarnya dipetakan, ditemukan bahwa didalam pengiriman akan menyeberangi jembatan yang sama dimana jembatan ini akan terjadi penumpukan. Maka seluruh operasi perusahaan akan berdampak negatif jika jembatan khusus ini ditutup. Dengan demikian, ketika rantai pasokan dipetakan, masalah segera terlihat alternatif jalan, seperti rerouting ke rute lain atau bentuk fasilitas lain yang jauh lebih mudah untuk dilewati. Perutean yang tepat dapat membantu organisasi mencapai prioritas kompetitif mereka dan meningkatkan profitabilitas rantai pasokan secara keseluruhan (Papinski \& Scott, 2011). Peta SIG tidak hanya gambar pada peta untuk para manajer, tetapi peta adalah variabel spasial. Integrasi data spasial bersama dengan data atribut membantu manajer melakukan "Bagaimana-jika analisis" dan benar-benar melihat implikasi/dampak dari hasil pada area operasi. Dengan demikian alat SIG perlu disesuaikan untuk memenuhi persyaratan manajer dan membantunya menjawab pertanyaan di atas untuk efisiensi operasi. SDSS (Wu et al., 2013)untuk analisis rute dan pembuatan rute dikembangkan menggunakan perangkat lunak yang dikembangkan oleh ESRI yaitu Arcgis. Kemampuan perangkat lunak Arcgis dengan kemampuan (Sandhu \& Chandrasekhar, 2006; Scott \& Janikas, 2010): Route Planning and Analysis, Asset Tracking, Navigation, Executive Dashboards, Business Development and Location Analysis, Going Green with GIS.

\section{KESIMPULAN}

Analisis SIG lebih dari penggunaan perangkat lunak pemetaan atau kemampuan untuk plot poin pada peta. Ini adalah kemampuan untuk menarik hubungan secara spasial dan untuk mengidentifikasi nilai dalam setiap hubungan. Kemampuan grafik dan tampilan jaringan SIG sangat cocok untuk manajemen rantai suplai. Fasilitas manufaktur dan distribusi dapat diwakili di peta. Sistem yang dikembangkan memungkinkan pembuat keputusan untuk memiliki informasi sebelumnya tentang jaringan jalan, jalur terpendek dan jalur alternatif antara fasilitas pabrik dan distribusi. Informasi ini dapat digunakan untuk membuat analisis perutean dan membantu organisasi mencapai prioritas kompetitif mereka dan meningkatkan profitabilitas rantai pasokan secara keseluruhan. Berdasarkan kecepatan perjalanan rerata waktu tempuh bisa dihitung. Kecepatan Travel bertindak sebagai proxy data lalu lintas (Sandhu \& Chandrasekhar, 2006).

SIG menyediakan lingkungan yang seragam untuk mengintegrasikan data untuk berbagai tujuan transportasi. Begitu spasial direferensikan, data dapat digunakan dalam banyak aplikasi lain, sehingga menambah nilai data dan nilai untuk proses perencanaan. Atribut data seperti sumber bahan yang masuk dan target pasar yang akan bergerak saham dapat diintegrasikan ke dalam SDSS yang dikembangkan. SDSS ini sekarang dapat digunakan dalam mengidentifikasi lokasi depot dan gudang (Zhang et al., 2016). Dengan demikian dengan mengintegrasikan data baru ke dalam SDSS yang bisa dikembangkan sebagai aplikasi baru. Meskipun aplikasi ini mungkin terlihat sederhana, memiliki potensi besar untuk profitabilitas karena manajer dapat melihat rute secara visual, lokasi, rute alternative secara live di computer ataupun handphone. Informasi ini dapat dikonversi dalam variabel bisnis seperti biaya, marjin kotor dan keuntungan untuk membuat keputusan bisnis yang efektif mengenai routing (Papinski \& Scott, 2011).

\section{DAFTAR PUSTAKA}

ESRI. (2019). An introduction to sampling/monitoring networks-Help | ArcGIS Desktop.

Irizarry, J., Karan, E. P., \& Jalaei, F. (2013). Integrating BIM and GIS to improve the visual monitoring of construction supply chain management. Automation in Construction.

https://doi.org/10.1016/j.autcon.2012.12.0 05

Lourenço, H. R., \& Ravetti, M. G. (2018). 
Supply chain management. In Handbook of Heuristics. https://doi.org/10.1007/9783-319-07124-4_54

Mambu, S., \& Wullur, M. (2017). Peta Potensi Halmahera Utara Menuju Kawasan Ekonomi Khusus. Jurnal Riset Ekonomi, Manajemen, Bisnis Dan Akuntansi.

Olson, D. L., \& Kesharwani, S. (2011). Enterprise information system trends. In Lecture Notes in Business Information Processing. https://doi.org/10.1007/978-3642-19802-1_1

Papinski, D., \& Scott, D. M. (2011). A GISbased toolkit for route choice analysis. Journal of Transport Geography. https://doi.org/10.1016/j.jtrangeo.2010.09. 009

Sandhu, J., \& Chandrasekhar, T. (2006). Network Analyst Tutorial. ArcGis9.

Scott, L. M., \& Janikas, M. V. (2010). Spatial Statistics in ArcGIS. In Handbook of Applied Spatial Analysis. https://doi.org/10.1007/978-3-642-036477_2

Wu, Y., Cegielski, C. G., Hazen, B. T., \& Hall, D. J. (2013). Cloud computing in support of supply chain information system infrastructure: Understanding when to go to the cloud. Journal of Supply Chain Management.

https://doi.org/10.1111/j.1745-

493x.2012.03287.x

Zhang, F., Johnson, D., Johnson, M., Watkins, D., Froese, R., \& Wang, J. (2016). Decision support system integrating GIS with simulation and optimisation for a biofuel supply chain. Renewable Energy. https://doi.org/10.1016/j.renene.2015.07.0 41 